\title{
Opacity in Crimean Tatar: The Interaction of Vowel Harmony and Syncope
}

\author{
DARYA KAVITSKAYA \\ University of California, Berkeley
}

\section{The Language}

Crimean Tatar (CT) is an understudied language of the West Kipchak branch of the Northwestern subgroup of the Turkic language family (Berta 1998, Doerfer 1959, Johanson 1998, Izidinova 1997, Kavitskaya 2010, Memetov 1993, Sevortian 1966, Useinov et al. 2005). CT is spoken mainly in the Ukraine's Crimean peninsula and in Uzbekistan, as well as in small communities in Russia, Bulgaria, Romania, and Turkey. The data used in this paper come from the author's fieldwork conducted in 2002, 2003, and 2009 in Crimea, Ukraine.

CT is traditionally subdivided into three dialects: Southern (or Coastal), Central, and Northern (or Steppe) (Berta 1998), even though this classification is a matter of some controversy. The Central dialect is now used as the standardized variety, while the number of speakers of the other two dialects is rapidly diminishing; they are severely endangered, especially the Northern dialect. This paper addresses mainly the data from the Central dialect of CT, pointing out similarities and differences with the other two dialects where necessary.

The sociolinguistic history of $\mathrm{CT}$ is complex and tragic, and the dialectological research is rather difficult. In 1944, all Crimean Tatars were deported from Crimea by the Soviet government, mainly to Uzbekistan, but also to other places in the former Soviet Union, including Kazakhstan, Tajikistan, and several locations in Russia (Fisher 1978). During the exile, the speakers of CT did not generally live in communities corresponding to their dialects and were surrounded by other Turkic languages, e.g., Uzbek, as well as non-Turkic languages, e.g., Russian. Crimean Tatars were only allowed to return to Crimea at the beginning of the 90s. Former inhabitants of certain areas of Crimea attempted to resettle in their native villages, but they encountered great difficulties in doing so and were forced to settle far from their original homes.

All these factors contributed to the dialect mixture. The dialectological distinctions are clear only in the speech of those consultants who were born and

preferably reached their teens before the time of the deportation. The data 


\section{Darya Kavitskaya}

collected from these older speakers of CT form the basis for the investigation presented in this paper. In what follows, we will discuss the data in Section 2, concentrating on vowel harmony, syncope, and stress. We will continue with an OT analysis of CT opacity in Section 3.

\section{$2 \quad$ Data}

The vowel system of the Central dialect of CT is presented in (1). ${ }^{1}$ The relevant contrasts are in vowel height, backness, and rounding.

(1) CT vowels

$\begin{array}{lllll} & \text {-back } & & \text { +back } & \\ & \text {-round } & \text { +round } & \text {-round } & \text { +round } \\ \text { +high } & \mathrm{i} & \mathrm{y} & \mathrm{u} & \mathrm{u} \\ \text {-high } & \mathrm{e} & \varnothing & \mathrm{a} & \mathrm{o}\end{array}$

A pilot study has shown that that $/ \mathrm{i} /$ and $/ \mathrm{u} / \mathrm{have}$ undergone a nearly complete phonetic merger (Kavitskaya 2010). However, they remain phonologically distinct, the high front unrounded vowel appearing in words with front harmony and the high back unrounded vowel in words with back harmony. Additionally, while /i/ acts as [-back] for the purposes of vowel harmony, it does not palatalize the preceding consonant, while its front rounded counterpart $/ y /$ causes the phonetic palatalization of the preceding consonant.

\subsection{Vowel harmony}

As in many other Turkic languages, all CT vowels participate in backness harmony (except for some disharmonic roots), as illustrated in (2) by the alternations in the verbal suffix /-mAK/: the value for the feature [back] in the suffix vowel depends on the backness of the root vowel(s).

(2) Backness harmony

$\begin{array}{llll}\text { bil-mek } & \text { 'know' } & \text { juv-maq } & \text { 'wash' } \\ \text { ket-mek } & \text { 'go' } & \text { qorq-maq } & \text { 'be afraid' } \\ \text { tyfyn-mek } & \text { 'think' } & \text { qur-maq } & \text { 'rub' } \\ \text { tøk-mek } & \text { 'pour' } & \text { ajlan-maq } & \text { 'turn' }\end{array}$

CT also exhibits rounding harmony. The harmony is triggered by any round vowel and targets high vowels. The rounding harmony in the Central CT differs

\footnotetext{
${ }^{1}$ An additional high front unrounded vowel phoneme was posited for the Northern dialect (Berta 1998).
} 
from a typical Turkic rounding harmony in that it is active only in the first two syllables of a word. When a suffix with a high vowel is added to a monosyllabic stem, as in (3a), its vowel agrees with the vowel of the stem in both backness and rounding. When such a suffix is added to a polysyllabic stem, rounding harmony does not target the vowel in the suffix, as in (3b). An example in (3c) illustrates that this is not morphologically conditioned: a stem vowel that is outside of the initial disyllabic window does not participate in rounding harmony either.

(3) Rounding harmony
a. dost-um
'friend-1SG.POSS'
kyz-lyk
bul-un-maq
'autumn-ADJ.SUF'
b. tuzluy-um
'find-PASS-INF'
'salt shaker-1SG.POSS'
tykyr-in-mek
'deportation-ADJ.SUF'
c. t $\int y k y n d i r$
'spit-PASS-INF'
'beets'

The loss of rounding beyond the second syllable of a word is attested in CT as early as at the beginning of the $20^{\text {th }}$ century (Samoilovich 1916, Bogoroditskii 1933) and thus cannot be ascribed to the influence of Uzbek, the most common contact language during the years of exile, many dialects of which lost harmony (Bodrogligeti 2003). In the Southern dialect of CT, rounding harmony affects all high vowels in a prosodic word (low vowels are blockers), and in the Northern dialect, rounding harmony is lost; the feature [round] is licensed only in the initial syllable of the word. There are other languages, such as Vogul, Bashkir, Ostyak, that behave like the Northern dialect of CT w.r.t. rounding harmony (Steriade 1995:161-162). The first syllable is also special in Karaim, a language closely related to CT: [back] contrasts among [-high] vowels and [+round] vowels in initial syllable only (Hamp 1976).

\subsection{Syncope}

Syncope in CT targets high vowels, both word-initially and word-medially. Syncope of a high vowel in an initial syllable can create word-initial complex onsets, as in (4) (even triconsonantal ones, as in (4b)). Otherwise, complex onsets are not tolerated in the native vocabulary. The vowel may delete even when it is the absolute initial position in a word, as shown in (4c).

(4) Word-initial syncope
a. kitap
[ktap]
'book'
tifim
[tfim]
'my tooth'
bilem
[blem]
'I know' 


\section{Darya Kavitskaya}

\begin{tabular}{|c|c|c|}
\hline b. sukmaq & [skmaq] & 'to push, press \\
\hline tuflemek & [tflemek] & 'to bite' \\
\hline qu & [qsqa] & 'short' \\
\hline iflemek & [ flemek] & 'to work' \\
\hline
\end{tabular}

Complex codas are maximally bi-consonantal and obey the Sonority Sequencing Principle, being only of rising sonority. Word-medially, syncope is blocked if it results in structures not acceptable by the phonotactics of the language. For instance, the high vowel in $(5 b)$ never deletes.

\section{Word-medial syncope}

$\begin{array}{lll}\text { a. aldular } & \text { [aldlar] } & \text { 'they took' } \\ \text { keldiler } & \text { [keldler] } & \text { 'they took' } \\ \text { otura } & \text { [otra] } & \text { 's/he sits' } \\ \begin{array}{l}\text { ketirip } \\ \text { epimiz }\end{array} & \text { [ketrip] } & \text { 'having brought' } \\ \text { b. øldyrmek } & \text { [øldyrmek] *[øldrmek] } & \text { 'all of us' } \\ \text { 'to kill' }\end{array}$

Word-initial and word-medial syncope are arguably not two different processes but rather different restrictions on word-initial vs. word-medial onsets (well attested in other languages; e.g., Georgian, famous for its complex onsets, only tolerates them word-initially).

If there is more than one high vowel in a word, the leftmost one undergoes deletion. As illustrated in (6), the deletion of the first vowel is preferred even though it creates an onset cluster, lexically unacceptable in CT, while the deletion of the second one would result in a word which is acceptable from the phonotactics' point of view.

(6) Syncope when there is more than one high vowel in a word ${ }^{2}$

$$
\begin{aligned}
& \text { tykyrem [ }\left[\mathrm{t}^{\mathrm{j}} \mathrm{k}^{\mathrm{j}} \mathrm{urem}\right] *\left[\mathrm{t}^{\mathrm{j}} \mathrm{ykrem}\right] \quad \text { 'I spit' } \\
& \text { pifirem [pfirem] *[pifrem] 'I cook' }
\end{aligned}
$$

Examples in (7) show that high vowels in final syllables, regardless of whether they are the absolute final vowels, as in (7a), or not, as in (7b), do not delete. We will discuss final stress in CT later.
a. berdi
[berdi]
*[berd] 'she gave'
b. ketirip
[ketrip] *[ketirp] 'having brought'

\footnotetext{
${ }^{2}$ There is a different kind of vowel/zero alternation in CT; a class of words like burun-um 'nose1SG.POSS,' which always surfaces as [burnum], and not *[brunum]. We analyze this word as /burn/ in the input with the epenthesis of a high vowel driven by the considerations of syllable structure.
} 
A spectrogram illustrating syncope is given in (8). Note that there is no trace of the first vowel present either in the sound wave or in the spectrogram. The first consonant is fricated and sounds palatalized.

(8)

/tykyrmek/ [ $\left.\mathrm{t}^{\mathrm{j}} \mathrm{kyrmek}\right]$ 'to spit'

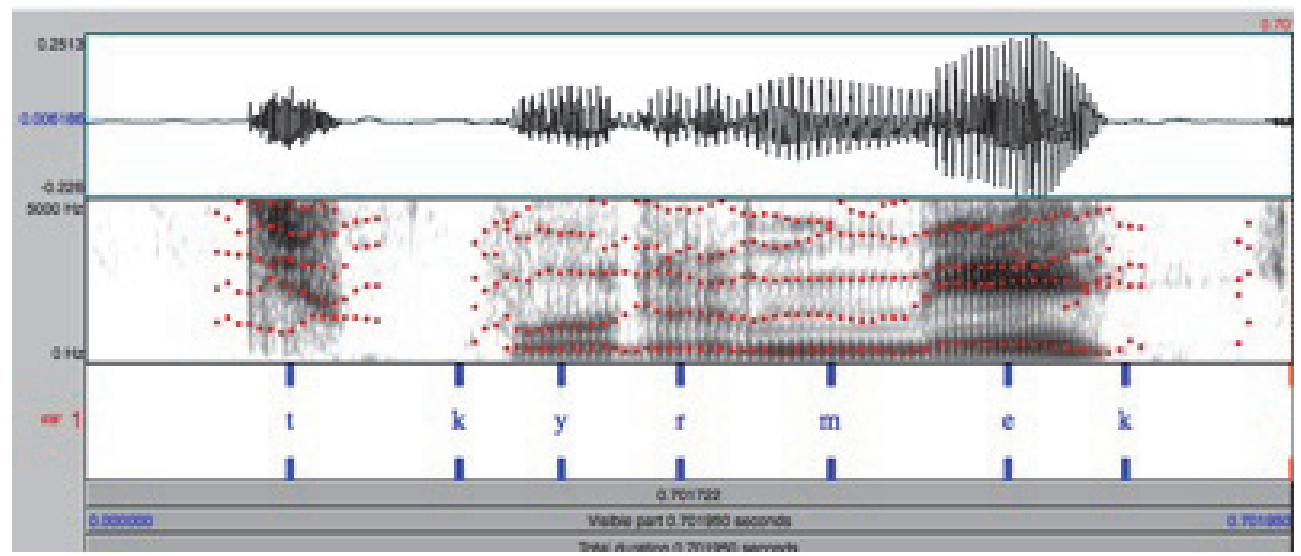

\subsection{Stress}

Each lexical word in Crimean Tatar has exactly one main stress. The default stress position is word-final, as shown it (9). It has been argued for Turkish (Levi 2005) that its default final stress is postlexical: it is predictable, not "strong," and native speakers are not aware of it. This seems to be the case for the related CT as well, even though more work is needed on the precise description of CT stress.

(9)

a. ara'ba 'cart'

araba-'lar 'carts'

cart-PL

araba-lar-'dan 'from carts'

cart-PL-ABL

b. bafla-'dur-m 'I began'

begin-PAST-1SG

bas-lar-umuz-'nu 'our heads'

head-PL-1PL.POSS-ACC

Final stress is overriden by lexical stress in roots and by pre-stressing suffixes. (10a) shows words that are lexically stressed on non-final syllables, examples of 


\section{Darya Kavitskaya}

verbs with the prestressing $1^{\text {st }}$ singular present suffix are in (10b), some examples of prestressing adverbial suffixes are in (10c), and the prestressing verbal negation suffix is in (10d).
a. 'nasul
'mitlaqa
'tezden
'which, how'
'definitely'
'quickly'
b. a'Jar-um
i't fer-im
'I eat'
'I drink'
c. ge'dze-lejin
afurq-t fan 'luq-nen
a'na-dzasuma
'at nights'
'in a hurry'
'in a motherly manner'
d. bar-'du 'he went' 'bar-ma-dur 'he didn't go' bil-'mek 'to know' 'bil-me-mek 'to not know'

Vowel harmony in CT is a lexical process, whose domain is a word. The behavior of /i/ as a front vowel for the purposes of vowel harmony and the fact that it does not trigger palatalization also points to the generalization that vowel harmony is a lexical process, while palatalization and syncope are both later processes. Palatalization is postlexical and, in rule terms, applies before phrasal syncope. The phrasal nature of syncope is illustrated by the example in (11), where the last vowel of the first word deletes by virtue of being not the last one in the phrase.

$$
\begin{array}{llll}
\text { baq-up } & \text { otur-a } & \text { [baq.pot.ra] 'looking at' } \\
\text { see-CONV } & \text { sit-PRES }
\end{array}
$$

\section{$3 \quad$ Analysis}

\subsection{Classic OT and CT opacity}

Harmony and syncope in CT interact opaquely. ${ }^{3}$ We will use rounding harmony as an example here, noting that most of what we say applies to backness harmony, unless specifically stated otherwise. In rule terms, the spreading of the feature [round] and the syncope of the high vowel in the first syllable are in a counterbleeding relation: were syncope ordered before harmony, no rounding of high vowels in non-initial syllables would be observed (12). ${ }^{4}$

\footnotetext{
${ }^{3}$ Here we will focus on the interaction of harmony and syncope, leaving out the discussion of the opaque interaction between syncope and palatalization. We will not show palatalization in the following examples.

${ }^{4}$ Additionally, the deletion of a rounded vowel in the first or second syllable makes the
} 
(12) Harmony and syncope in rule terms: tyf-Ir-Em 'fall-CAUS-STEMV1SG.PRES'
a. UR
tyf-Ir-E-m
b. UR
tyf-Ir-E-m
1. Harmony
tyfyrem
2. Syncope
t fyrem
Surface
t fyrem

$\begin{array}{ll}\text { 1. Syncope } & \text { tfIrEm } \\ \text { 2. Harmony } & \text { tfirem } \\ \text { Surface } & * t \text { firem }\end{array}$

As is extensively discussed in recent phonological literature, opaque interactions present a problem for classic OT (see an overview in McCarthy 2007). A possible classic OT account of the interaction of syncope and harmony in CT would require an AGREE $^{5}$ constraint to account for harmony, but it would be irrelevant in the case of opacity we discuss, so it is omitted from the discussion and the tableau.

Constraints that address rounding harmony are in (13) and (14).

LICENSERD $(\sigma \sigma)\left(\right.$ after Walker 2005) ${ }^{6}$

Feature [round] must be associated to positions in two syllables.

(14) DEP(round): Assign a violation mark for every instance of the feature [round] in the output that has no correspondent in the input (=don't insert the feature [round]).

The constraints in (15) and (16) account for syncope. The *Nuc/X constraints drive differential syncope that only targets high vowels. The ranking in (15) states that having high vowels in the nucleus of a syllable is worse than having non-high vowels in this position. MAXV is a constraint on vowel deletion.

*Nuc/i,u,y,u >> *Nuc/e,o,a,ø (informally, *Nuc/high >> *Nuc/low) (Gouskova 2003 on differential syncope, see also Prince and Smolensky 1993, de Lacy 2004, 2006).

(16) MAXV: Assign a violation mark for every input vowel that has no output correspondent (=do not delete a vowel).

The tableau in (17) illustrates the nature of the problem. There is no possible ranking under which the opaque candidate (17c) would emerge as the winner; it is harmonically bound. The LICENSERD constraint does not make a choice between

requirement that the feature [round] is realized over two syllables opaque.

${ }^{5}$ To be replaced with SHARE on the basis of recent work by John McCarthy (McCarthy 2003, 2008, 2009) and others, and to be kept according to some other views, e.g., the recent book by Andrew Nevins (Nevins 2010).

${ }^{6}$ The idea behind LiCENSE(Feature, S-Position) is that a feature be affiliated with a perceptually strong position. The initial position is strong, however, it is not sufficient to license [round] in CT. 
transparent candidates $(17 \mathrm{~b})$ and $(17 \mathrm{~d})$, and $*$ NuC/hi would rule out $(17 \mathrm{~b})$ (a candidate with no syncope), but the transparent (17d) would still win.

CT opacity in classic OT

\begin{tabular}{|c|c|c|c|c|}
\hline /tyf-Ir-Em/ & LICENCERD $(\sigma \sigma)$ & *NuC/hi & $\mathrm{DEP}[\mathrm{rd}]$ & MAXV \\
\hline a. tysirem & 1 & 2 & & \\
\hline b. ty $\int y r e m$ & & 2 & 1 & \\
\hline : c. t tyrem & 1 & 1 & 1 & 1 \\
\hline d. t firem & & 1 & & 1 \\
\hline e. tyfrem & 1 & 1 & & 1 \\
\hline
\end{tabular}

\subsection{OT-CC and CT opacity}

We will now outline an account of opacity in CT with OT with candidate chains (OT-CC, McCarthy 2007), a theory specifically developed to remedy the problem with opacity.

In OT-CC, the output is reached from the input via a series of steps (represented as a candidate chain); OT-CC is thus a version of Harmonic Serialism. From this follows a harmonic improvement requirement: each step in a chain must improve harmony. A gradualness requirement on the formation of a candidate chain holds that there should be one violation of one basic faithfulness constraint per step (dubbed as a localized unfaithful mapping, or LUM, in McCarthy 2007). The first step represents the most harmonic faithful parse of the input. Each chain has a correspondent set of localized faithful mappings (the ${ }^{\mathrm{a}}$-set) and an ordering of the elements in the set (the rLUMSeq).

To illustrate the generation of candidate chains, for the input/tyfirem/ our constraints generate six harmonically-improving chains, shown in (18). Only these chains are the possible candidates under the OT-CC formalism. (18a) is the most harmonic faithful parse, and thus both sets of localized faithful mappings and an ordering of the elements are empty. (18b) is the candidate with harmony, where DEP(round) is violated. (18c) is a transparent candidate with the syncope of the first high vowel, and (18d) is also transparent, but with the syncope of the second high vowel. (18e) is an opaque candidate with both harmony and syncope, and (18f) is just like (12e), the difference being that the second and not the first vowel is deleted.

(18) Valid chains for the input /tyf-ir-em/ 'I drop'
a. $<$ tyfirem $>$
$\varnothing, \varnothing$ (faithful)
b. $<$ tyfirem, tyfyrem $>$
$\{$ DEP(rd)@4\},Ø
c. $<$ tyfirem, t $f$ irem $>$
\{MAxV@2\},Ø
d. $<$ tyfirem, tyfrem $>$
\{MAxV@4\},Ø 
e. <tyfirem, tyfyrem, tfyrem> $>$ DEp(rd)@4, MAXV@2\}, $\{<\mathrm{DEP}(\mathrm{rd}) @ 4, \operatorname{MAXV} @ 2>\}$

f. <tyfirem, tyfyrem, tyfrem> $>$ DEP(rd)@4, MAXV@4\}, $\{<\mathrm{DEP}(\mathrm{rd}) @ 4, \operatorname{MAXV} @ 4>\}$

In OT-CC, we account for opacity with a precedence constraint $\operatorname{PREC}(\mathrm{A}, \mathrm{B})$, where $\mathrm{A}$ and $\mathrm{B}$ are faithfulness constraints, which requires that all violations of $\mathrm{B}$ are preceded by and not followed by violations of $A$. The technical definition of $\operatorname{PreC}(\mathrm{A}, \mathrm{B})$ is in (19).

PreC(A, B)(cand) (McCarthy 2007: 98)

Let $\mathrm{A}^{\prime}$ and $\mathrm{B}^{\prime}$ stand for LUMs that violate the faithfulness constraints A and B, respectively.

Let cand $=\left(\right.$ in, out, ${ }^{\mathrm{a}}$-set, rLUMSeq)

i. $\forall \mathrm{B}^{\prime} \in^{\mathrm{a}}$ assign a violation mark if $\exists \neg \mathrm{A}^{\prime} \in^{\mathrm{a}}$ where $\left\langle\mathrm{A}^{\prime}, \mathrm{B}^{\prime}>\in\right.$ $\mathrm{rL}$

ii. $\forall \mathrm{B}^{\prime} \in^{\underline{\underline{a}}}$ assign a violation mark if $\exists \neg \mathrm{A}^{\prime} \in^{\underline{\underline{a}}}$ where $<\mathrm{B}^{\prime}, \mathrm{A}^{\prime}>\in \mathrm{rL}$

To account specifically for opacity in CT, PREC(DEP(round), MAXV) requires violations of DEP(round) (harmony) to precede and not follow violations of MAXV (syncope), that is, harmonize first, delete after that.

The tableau in (20) illustrates the analysis, as well as a problem associated with it. The constraints proposed above can indeed account for opacity, but they are not capable of choosing the candidate with the correct syncope site. That is, there is nothing that can select the actual candidate (20e), where the first vowel is deleted, over the candidate (20f), where the second vowel is deleted. 


\begin{tabular}{|c|c|c|c|c|c|}
\hline /tyfirem/ & *NuC/hi & MAXV & $\begin{array}{l}\text { PREC(DeP(rd), } \\
\text { MAXV) }\end{array}$ & $\operatorname{LicRD}(\sigma \sigma)$ & $\operatorname{DEP}(\mathrm{rd})$ \\
\hline $\begin{array}{c}\text { a. }<\text { ty } \text { firem }> \\
\varnothing, \varnothing\end{array}$ & $\mathrm{W}_{2}$ & $\mathrm{~L}$ & & 1 & $\mathrm{~L}$ \\
\hline $\begin{array}{l}\text { b. }<\text { tyfirem, } \\
\text { tyfyrem }> \\
\{\text { DEP[rd]@4\}, } \varnothing\end{array}$ & $\mathrm{W}_{2}$ & $\mathrm{~L}$ & & L & 1 \\
\hline 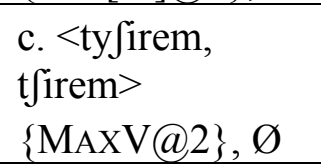 & 1 & 1 & $\mathrm{~W}_{1}$ & $\mathrm{~L}$ & $\mathrm{~L}$ \\
\hline $\begin{array}{l}\text { d. }<\text { tyfirem, } \\
\text { tyfrem> } \\
\{\text { MAX@4\}, } \varnothing\end{array}$ & 1 & 1 & $\mathrm{~W}_{1}$ & 1 & $\mathrm{~L}$ \\
\hline $\begin{array}{l}\odot \text { e. }<\text { tyfirem, } \\
\text { tyfyrem, tfyrem }> \\
\{\text { DEP[rd]@ } 4, \\
\text { MAX@2\} }\end{array}$ & 1 & 1 & & 1 & 1 \\
\hline $\begin{array}{l}\odot \text { f. }<\text { tyfirem, } \\
\text { tyfyrem, tyfrem }> \\
\{\text { Dep[rd]@4, } \\
\text { MAX@4\} }\end{array}$ & 1 & 1 & & 1 & 1 \\
\hline
\end{tabular}

As was mentioned before, we cannot assume that the deletion of the first vowel happens over the deletion of the second vowel for the reasons of syllable structure, because the form in (20f) with the deleted second vowel is fully acceptable from the point of view of CT phonotactics (and if anything, is better than the actual winner in (20e)). In addition, CT does not show any evidence for secondary stress or further footing so CT syncope is different from the welldescribed metrical syncope and cannot be derived by metrical constraints.

To solve this problem, we need to consider CT stress. From the data we observe that in CT the prominence status of the initial syllable is different for different processes. The initial syllable is a common privileged position associated in the literature with phonological strength effects (see Barnes 2006; Beckman 1997; Kaun 1995, 2004). It is a strong position in CT as well, as shown by the fact that it licenses the feature round (note that in the Northern dialect of $\mathrm{CT}$ rounding is limited to the initial syllable). However, the same initial position is also weak, and is thus the best syncope site, as it is the furthest away from the final stress. The conflicting requirements on prominence are the source of opacity 
in the system.

Some support for this generalization is provided by words like [nasul] 'which, how', stressed on the first syllable. The second vowel is high and can be reduced, however, it is never fully deleted since the deletion of it would create a rising sonority coda. There is also work that shows that the coarticulation patterns in Turkish are stronger from right to left (Beddor and Yavuz 1995). If it works the same way in CT (which remains to be checked), it would also support the generalization.

To formalize the proposal, we modify OT-CC to include a family of constraints on the preference of the direction of iteration, $\operatorname{PREFER}\left(\mathrm{F}_{\mathrm{x}}, \mathrm{F}_{\mathrm{x}+1}\right)$, where $F$ is a faithfulness constraint. The definition of $\operatorname{PREFER}\left(F_{x}, F_{x+1}\right)$ is provided in (21).

(21) Prefer $\left(\operatorname{MAX}_{x}, \operatorname{MAX}_{x+1}\right)$ : Assign one violation mark for a candidate chain that has a violation of MAX and a competitor chain in which this violation occurs earlier in the form.

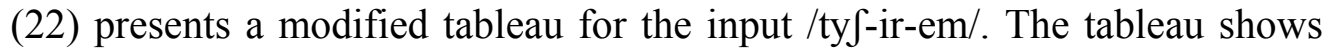
that the introduction of PREFER solves the problem; the correct candidate chain (22e) is picked as the winner. 
(22) A tableau for the input/tyf-ir-em/ 'I drop'

\begin{tabular}{|c|c|c|c|c|c|c|}
\hline /tyfirem/ & $\begin{array}{l}{ }^{*} \mathrm{NuC} / \\
\mathrm{hi}\end{array}$ & $\begin{array}{l}\text { MAX } \\
\mathrm{V}\end{array}$ & $\begin{array}{l}\text { PreC(DeP(r } \\
\text { d), MAXV) }\end{array}$ & $\begin{array}{l}\text { PREFER(MA } \\
\left.X_{X}, M_{X_{X}+1}\right)\end{array}$ & $\begin{array}{l}\operatorname{LICRD}(\sigma \\
\sigma) \\
\end{array}$ & $\begin{array}{l}\text { DEP(r } \\
\text { d) }\end{array}$ \\
\hline $\begin{array}{c}\text { a. }<\text { ty } \int \text { irem }> \\
\varnothing, \varnothing\end{array}$ & $\mathrm{W}_{2}$ & $\mathrm{~L}$ & & & 1 & $\mathrm{~L}$ \\
\hline $\begin{array}{l}\text { b. <tyfirem, } \\
\text { tyfyrem> } \\
\{\text { Dep[rd]@4 } 4 \\
\}, \varnothing\end{array}$ & $\mathrm{W}_{2}$ & $\mathrm{~L}$ & & & $\mathrm{~L}$ & 1 \\
\hline $\begin{array}{l}\text { c. }<\text { tyfirem, } \\
\text { tfirem> } \\
\{\text { MAXV@2 } \\
\}, \varnothing\end{array}$ & 1 & 1 & $\mathrm{~W}_{1}$ & & $\mathrm{~L}$ & L \\
\hline $\begin{array}{l}\text { d. <tyfirem, } \\
\text { ty }\{\mathrm{rem}> \\
\{\operatorname{MAX} @ 4\}, \\
\varnothing\end{array}$ & 1 & 1 & $\mathrm{~W}_{1}$ & $\mathrm{~W}_{1}$ & 1 & $\mathrm{~L}$ \\
\hline $\begin{array}{l}\odot \text { e. } \\
<\text { tyfirem, } \\
\text { tyfyrem, } \\
\text { tfyrem> } \\
\{\text { Dep[rd]@4 } 4 \\
\text { MAX@2\} }\end{array}$ & 1 & 1 & & & 1 & 1 \\
\hline 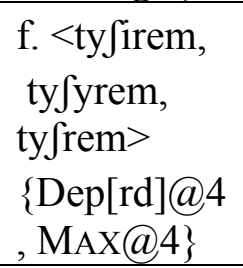 & 1 & 1 & & $\mathrm{~W}_{1}$ & 1 & 1 \\
\hline
\end{tabular}

\section{Conclusions}

To conclude, we have argued that conflicting prominence in CT is the source of opacity. The initial syllable is the most prominent for vowel harmony and licenses the most contrasts. However, it is also the least prominent, being the furthest away from stress, and thus is the best site for syncope. The decision between the initial and medial syncope cannot be made by metrical constraints since there is no evidence for further footing in CT, beyond the final stressed syllable. In order to account for these data, we proposed a constraint on the preference of the direction of iteration.

There are two venues that need to be explored in future research. First, the 


\section{Opacity in Crimean Tatar}

typological consequences of the PREFER constraint family are unclear and need to be addressed. Second, the Lexical Phonology and Morphology (Kiparsky 2000, among others) appears to be a theory that can naturally handle the CT problem, but stumbling upon the very issue with syncope, which needed to be resolved with the introduction of PREFER. It is possible that further investigation will reveal additional data on stress and footing that will point to a metrical solution.

\section{References}

Barnes, Jonathan. 2006. Strength and Weakness at the Interface: Positional Neutralization in Phonetics and Phonology. Walter de Gruyter.

Beckman, Jill. 1997. Positional faithfulness, positional neutralisation and Shona vowel harmony. Phonology 14:1-46.

Beddor, Patrice S., and H.K. Yavuz. 1995. The relation between vowel-to-vowel coarticulation and vowel harmony in Turkish. In K. Elenius and P. Branderud, eds., Proceedings of the $13^{\text {th }}$ International Congress of Phonetic Sciences, vol. 2, 44-51. Stockholm: KTH and Stockholm University.

Berta, Árpád. 1998. West Kipchak languages. In L. Johanson, \& E. Csato, eds., The Turkic languages. New York: Routledge. 301-317.

Bodrogligeti, Andras. 2003. An Academic Reference Grammar of Modern Literary Uzbek. Munchen: LINCOM Europa.

Bogoroditskii, V.A. 1933. Dialektologicheskie zametki. V. O krymsko-tatarskom narechii. Kazan.

de Lacy, Paul. 2004. Markedness conflation in Optimality Theory. Phonology 21:145-199.

de Lacy, Paul. 2006. Markedness: reduction and preservation in phonology. Cambridge, CUP.

Doerfer, G. 1959. Das Krimtatarische. In J. Deny et al, eds. Philologiae Turcicae Fundamenta I, Wiesbaden: Steiner, 369-390.

Fisher, Alan W. 1978. The Crimean Tatars. Hoover Institution Press, Stanford University, Stanford, California.

Gouskova, Maria. 2003. Deriving economy: syncope in Optimality Theory. Ph.D. thesis, University of Massachusetts, Amherst. 


\section{Darya Kavitskaya}

Hamp, Eric. 1976. Palatalization and harmony in Gagauz and Karaite. In W. Heissig, J. R. Krueger, F. J. Oinas, and E. Schütz, eds., Tractata altaica: Denis Sinor, sexagenario optime de rebus altaicis merito dedicata, 211-213. Wiesbaden: Harrasowitz.

Izidinova, S.R. 1997. Krymskotatarskii iazyk. In E.R. Tenishev, ed., Iazyki mira. Tiurkskie iazyki. Moscow: Indrik.

Johanson, Lars. 1998. The history of Turkic. In Johanson, L. \& E. Csato, eds. The Turkic languages. New York: Routledge. 81-125.

Kaun, Abigail. 1995. The typology of rounding harmony: an Optimality Theoretic approach. Ph.D. thesis, UCLA.

Kaun, Abigail. 2004. In Bruce Hayes, Robert Kirchner, and Donca Steriade, eds. Phonetically Based Phonology. Cambridge University Press.

Kavitskaya, Darya. 2010. Crimean Tatar. LINCOM Europa.

Kiparsky, Paul. 2000. Opacity and cyclicity. The Linguistic Review. 17: 351-367.

Levi, Susannah V. 2005. Acoustic correlates of lexical accent in Turkish. JIPA 35:73-97.

McCarthy, John J. 2003. OT constraints are categorical. Phonology 20:75-138.

McCarthy, John J. 2007. Hidden Generalizations. Equinox, London.

McCarthy John J. 2008. The serial interaction of stress and syncope. NLLT 26:499-546.

McCarthy, John J. 2009. Harmony in harmonic serialism. Unpublished manuscript, University of Massachusetts, Amherst. ROA-1009.

Memetov, A. 1993. Krymskie tatary: istoriko-lingvisticheskii ocherk. Simferopol: Anaiurt.

Nevins, Andrew. 2010. Locality in Vowel Harmony. Cambridge, Mass.: MIT Press.

Prince, Alan \& Paul Smolensky. 1993. Optimality Theory: constraint interaction in generative grammar. Ms, Rutgers University \& University of Colorado, Boulder. Published 2004, Malden, Mass. \& Oxford: Blackwell. 
Samoilovich, A. N. 1916. Opyt kratkoi krymsko-tatarskoi grammatiki. Petrograd.

Sevortian, E. 1966. Krymskotatarskii iazyk. In N. Baskakov et al, eds., Iazyki narodov SSSR 2, Nauka, 234-259.

Steriade, Donca. 1995. Underspecification and markedness. In John Goldsmith, ed., The Handbook of Phonological Theory. Cambridge, MA: Blackwell Publishers.

Useinov, S., V. Mireev, \& V. Sahadzhiev. 2005. Q1rımtatar tilini ögreniñiz. Simferopol: Ocaq.

Walker, Rachel. 2005. Weak triggers in vowel harmony. NLLT 23:917-989.

Darya Kavitskaya

University of California, Berkeley

Department of Slavic Languages and Literatures

6219 Dwinelle Hall

Berkeley, CA 94720-2650

dkavitskaya@berkeley.edu 